\title{
What Determines Generation Z Continuance Intention of Fintech? The Moderating Effect of Gender
}

\author{
Ferina Nurlaily*, Edlyn Khurotul Aini, Priandhita Sukowidyanti Asmoro \\ Department of Business Administration \\ Universitas Brawijaya \\ Malang, Indonesia \\ *ferinanurlaily@ub.ac.id, edlynaini@ub.ac.id, priandhita.sa@ub.ac.id
}

\begin{abstract}
This study examines the effect of perceived risk and benefits on Financial Technology (FinTech) continuance intention among Generation $Z$ in Indonesia. Additionally, the different effects of gender as one of the demographic factors were as well analyzed. The sample of 248 respondents was involved with a focus specifically on Generation $Z$ in Indonesia, aiming an effects analysis between variables and moderating role of gender in consumer continuance intention to use FinTech. Multiple regression analysis was used to examine the hypothesis using SPSS and SPSS Process Software. The finding confirmed that perceived benefit has played a substantial role in improving the continuance intention of consumers to use FinTech. On the contrary, perceived risk gives no significant effect on FinTech continuance intention among Generation $Z$. This study also revealed that gender moderation was found in perceived risk instead of perceived benefit on FinTech continuance intention. This study provides a useful overview regarding FinTech to develop an effective strategy in targeting Generation $Z$ consumers and attempts to deliver an insight on whether the constant use of FinTech is affected by consumers' perceived risk or benefit.
\end{abstract}

Keywords-perceived benefit, perceived risk, financial technology, continuance intention, Generation Z

\section{INTRODUCTION}

A fast-paced development of information technology brings a rapid growth in financial services attributed as well with the touch of technology, termed as Financial Technology (FinTech). Numbers of FinTech companies have been empowering mobile platforms where previously online platforms were brought into play. Bank Indonesia (BI) declared that FinTech is a combination of financial service and technology which eventually turns the business model from conventional into a moderate state, where the face-to-face payments are no longer needed since any transactions nowadays can be done remotely and instantly (bi.go.id). International Monetary Fund (IMF) described FinTech as the technology-enabled innovation in financial services that can manifest new models of business, applications, processes, or products with a related material effect on the provision of financial services. Besides, Bank Indonesia categorizes
FinTech into four types: 1) crowdfunding or peer to peer lending; 2) market aggregator; 3) risk and investment management; and 4) payment, settlement, and clearing.

The advent of FinTech can be considered as the effect of altered lifestyle in today's world since the majority of people have been dominated by technology users who prefer practicality and immediate actions in every aspect. The use of FinTech can cut back various obstacles in transactions and payments, for instance, getting no time for offline shopping, unavailable to proceed remittance via bank/ATM, and being reluctant to visit a particular place due to the unsatisfying services. In other words, FinTech supports buy and sell transactions and creates more efficient and economical yet effective payment systems. FinTech provides a brand new opportunity to empower people through transparency, reducing cost, removing the barrier, and make the financial information easy to access [1].

In this pandemic situation, FinTech industries are expected to play an important role and take the opportunity to evoke financial inclusion and contribute to national economic growth by benefitting its excellence in technology. More specifically, an investigation carried out by Institute for Development of Economics and Finance (INDEF) in June 2020 depicted FinTech's contribution to Gross Domestic Product (GDP) in 2019 reached to IDR 60 trillion. This amount indicates a $131 \%$ leap from the previous year which only framed at IDR 25.97 trillion. In 2020, FinTech has contributed to GDP for over IDR 100 trillion.

EY revealed that global consumer FinTech adoption was at $64 \%$ in 2019, showing an increase from 33\% in 2017. Conforming to that, Awareness of FinTech worldwide also depicted a high number. Based on the data, $96 \%$ of consumers find out more than one alternative FinTech service available to help them transfer money and make payments. In Indonesia, the growth of FinTech industries is quite noticeable. It had been proven statistically where 99 FinTech lending companies were recorded to have been registered and licensed at the Financial Services Authority and 54 FinTech payment systems registered with Bank Indonesia (BI) (ojk.go.id), even these numbers are expected to keep growing in the upcoming years. 
Based on those data it can be confirmed that FinTech in Indonesia has experienced development, but the growth is unfortunately still lagging behind other Asia countries such as China, Hong Kong, and India. McKinsey \& Company's annual report conveys that the penetration rate of financial services utilization through FinTech in Indonesia is still around 5\%, distinctively lower than China with 67\%, Hong Kong 57\%, and India $39 \%$.

As a part of technological development, the possible users of FinTech would be those who are close and familiar to the internet and technology, taking an example, the Generation Z . This generation belongs to the people born in 1995 and above (https://www.pewsocialtrends.org). In Indonesia, Generation Z reached up to 72.8 million (27\%) out of 267 million from the total population by the year 2019 with 44 million internet users coming from Generation $\mathrm{Z}$ (lokadata.id). Generation $\mathrm{Z}$ consumes more massively compared to X-Generation and $\mathrm{Y}$ Generation, notably due to the use of technology, thus, Generation $Z$ is labeled "mobile generation" (nasional.sindonews.com). The fact that Generation $\mathrm{Z}$ is the largest population, active in using technology and accustomed to cashless lifestyle, permit a huge potential of this generation to be the FinTech users. This habit is worth investigating, in term to their preferences to use FinTech services in Indonesia.

Lots of attention has been paid on the benefits as well as the doubts about using FinTech constantly. The presence of considerable risk in FinTech makes some users become skeptical to keep using it. A research conducted by Padmanaban and Soo [2] found that $82 \%$ of financial institution respondents were concerned about the threat posed by FinTech. In Indonesia, even though BI and OJK have already legitimized the regulations regarding registration and operation of FinTech, illegal FinTech industries still exist in a large number and raise concern for users. Investment Alert Task Force (Satgas Waspada Investasi) found out 508 entities of illegal peer to peer lending FinTech that were not registered in OJK from January to March 2020. Those illegal FinTech made some investment offers without any legal permission and led to the potential public fraud by offering extremely high and unreasonable returns. Consequently, those unexpected risks of FinTech may negatively influence users' experience and prevent their continued use. If FinTech companies disable to retain their customers to continue using their services, longterm success is impossible to achieve.

In customers' perspective, before deciding to use any kind of item or service, the benefits and risks are strongly put into consideration. Customers will most likely prefer using a good or service in a sustainable manner when they find it more beneficial instead of risky. Therefore, FinTech companies are challenged to upsurge the potential gains of FinTech, while minimizing its risks [3]. Hence, it is important to have an indepth understanding of customers' perceptions toward FinTech to enhance the FinTech continuance intention in Indonesia. The perceived benefit can be defined as the way customers think about the positive outcome that FinTech Continuance Intention will potentially deliver, while the perceived risk is defined as customers' perception regarding any possible negative consequences and uncertainty of FinTech continuance intention [4]. Based on Reasoned Action Theory, FinTech Continuance Intention depends on the way customers behave towards FinTech, affected by behavioral beliefs. More specifically, benefits and risks of using FinTech can be reckoned as behavior (positive and negative), beliefs that manifest attitudes and subsequent behavioral intentions, and actions [5].

Prior studies spotted the main antecedents affecting user behavioral intentions [6-9]. Furthermore, Rouibah et al. [10] described that the demographic factor such as gender will play an important role as a moderating variable that affects technology adoption. It happens conceivably due to different behaviors underlying females and [11]. Another study had also been carried out to analyze gender difference issue in the adoption of mobile [12], but less attention had been paid to the role of gender in the relationship between perceived benefit, perceived risk, and FinTech continuance intention particularly in Indonesia. In accordance to World Bank data in 2017, as much as $51.4 \%$ of online platforms users on financial institution in Indonesia was comprised by women while the remaining $46.2 \%$ was owned by men. This portrays the possibility of different perceptions that exist among men and women regarding the risks and benefits from using FinTech following an impact on its continuance intention. To bridge these research gaps, this paper has two major contributions: first to determine how perceived benefits and perceived risks influence the continuous use of FinTech, and secondly, to examine how those effects are further moderated by gender as one of the consumer demographics.

Based on the theoretical background and empirical evidence of the literature review, this study hypothesizes that:

H1: Perceived benefit has a significant effect on FinTech continuance intention

H2: Perceived risk has a significant effect on FinTech continuance intention

H3: The effect of perceived benefit on FinTech continuance intention is moderated by gender

H4: The effect of perceived risk on FinTech continuance intention is moderated by gender

\section{METHODS}

\section{A. Sample and Data Collection}

The samples in this study were Generation $\mathrm{Z}$ who used FinTech. This research used primary data collected through online survey which was conducted by distributing 300 questionnaires to the respondents. However, from 300 questionnaires distributed only 248 questionnaires were returned back successfully to the researcher, giving $83 \%$ rate of responses. It is considered sufficient as is conformed to Sekaran [13], mentioning $75 \%$ as acceptable rate for statistical reliability. Table 1 shows the characteristics of the respondents. 


\section{B. Measurement}

To attained content validity approach, the measurement items were implemented based on the intensive literature review [14,15]. Comprehensive multiple-item measurements were developed based on previous literature in measuring perceived benefit, perceived risk, and continuance intention of FinTech. Perceived benefit was defined as positive behavioral towards advantage beliefs which establish attitudes and further behavioral intention and actions [14,16]. The proposed measurements of perceived benefit contain 6 items. Perceived risk reflects user perception of uncertainty its outcome as well as the magnitude of the consequences of making a wrong decision $[14,17,18]$. The measurement of perceived risk consists 5 items. Furthermore, continuance intention of Fintech is defined as a consideration whether to push through adoption of Fintech [14]. The item of continuance intention of Fintech composes 4 items. A pre-test was performed beforehand to examine the reliability and validity of the instruments, subsequently followed by the main survey. The questionnaire was provided to 30 respondents to further examine its reliability and validity. The measures were evaluated with a five-point Likert-type scale, ranging from "extremely disagree" (1) to "extremely agree" (5). Table II shows the result of validity and reliability test.

\section{RESUlTS}

\section{A. Validity and Reliability Test}

The results of the questionnaires which have been distributed to Generation $\mathrm{Z}$ and FinTech users are described in the table 1 . The data shows that $89.52 \%$ of respondents' age were ranging from 20-25 years old, while the gender which acted as variable moderator yielded a female:male ratio of $59.27 \%$ to $40.73 \%$. The majority of educational levels were around undergraduate or Diploma III with a percentage of $50 \%$. Furthermore, the respondents were dominated by early adopter who had the speed ahead of using technology. Based on their origins, it can be concluded that the respondents came from all over Indonesia.

TABLE I. THE CHARACTERISTICS OF THE RESPONDENTS

\begin{tabular}{|l|l|l|l|}
\hline Variable & \multicolumn{1}{|c|}{ Group } & Frequency & Percent \\
\hline \multirow{4}{*}{ Age } & $\begin{array}{l}<20 \text { years old (minimum ban } \\
\text { at 15 years old) }\end{array}$ & 26 & $10,48 \%$ \\
\cline { 2 - 4 } & $20-25$ years old & 222 & $89,52 \%$ \\
\hline \multirow{3}{*}{ Gender } & Female & 147 & $59,27 \%$ \\
\cline { 2 - 4 } & Male & 101 & $40,73 \%$ \\
\hline \multirow{3}{*}{$\begin{array}{l}\text { Education } \\
\text { Level }\end{array}$} & $<$ Diploma III & 121 & $48,79 \%$ \\
\cline { 2 - 4 } & Undergraduate or Diploma III & 124 & $50 \%$ \\
\cline { 2 - 4 } & Master Degree & 3 & $1,21 \%$ \\
\hline \multirow{3}{*}{$\begin{array}{l}\text { User } \\
\text { types }\end{array}$} & Early adopter & 210 & $84,68 \%$ \\
\cline { 2 - 4 } & Late adopter & 38 & $15,32 \%$ \\
\cline { 2 - 4 } Origin & Sumatra & 21 & $8,47 \%$ \\
\cline { 2 - 4 } & Java & 210 & $84,68 \%$ \\
\cline { 2 - 4 } & Kalimantan & 11 & $4,44 \%$ \\
\cline { 2 - 4 } & Sulawesi & 2 & $0,8 \%$ \\
\cline { 2 - 4 } & Nusa Tenggara & \\
\hline
\end{tabular}

TABLE II. THE CHARACTERISTICS OF THE RESPONDENTS

\begin{tabular}{|c|c|c|c|}
\hline & Item & $\mathbf{r}$ & Cronbach $\alpha$ \\
\hline \multirow{6}{*}{ Perceived Benefit } & PB 1 & $0.713^{\mathrm{a}}$ & \multirow{6}{*}{0.783} \\
\hline & PB 2 & $0.742^{\mathrm{a}}$ & \\
\hline & PB 3 & $0.561^{\mathrm{a}}$ & \\
\hline & PB 4 & $0.795^{\mathrm{a}}$ & \\
\hline & PB 5 & $0.761^{\mathrm{a}}$ & \\
\hline & PB 6 & $0.594^{\mathrm{a}}$ & \\
\hline \multirow{5}{*}{ Perceived Risk } & PR 1 & $0.564^{\mathrm{a}}$ & \multirow{5}{*}{0.753} \\
\hline & PR 2 & $0.842^{\mathrm{a}}$ & \\
\hline & PR3 & $0.745^{\mathrm{a}}$ & \\
\hline & $\mathrm{PR} 4$ & $0.708^{\mathrm{a}}$ & \\
\hline & PR 5 & $0.688^{\mathrm{a}}$ & \\
\hline \multirow{4}{*}{ FinTech Continuance Intention } & FCI 1 & $0.760^{\mathrm{a}}$ & \multirow{4}{*}{0.846} \\
\hline & FCI 2 & $0.803^{\mathrm{a}}$ & \\
\hline & FCI 3 & $0.858^{\mathrm{a}}$ & \\
\hline & FCI 4 & $0.885^{\mathrm{a}}$ & \\
\hline
\end{tabular}

Notes: $r$ table $0.312(\mathrm{df}=28, \mathrm{p}<0.05)$; ${ }^{\mathrm{a}}$ Correlation is significant at the 0.01 level $(2$-tailed

Reliability test was performed to examine the internal consistency of the data. Commonly, it uses Cronbach Alpha coefficient to determine the value. The Cronbach Alpha Coefficient has to be above or at 0.7 in order to attain a meaningful internal consistency or reliable value. The value at over 0.7 is considered acceptable, while the lower portion indicates a poor value [19]. Turning to the results in table 2, the Cronbach Alpha shows the values above 0.7 in all 2 independent and 1 dependent variables, suggesting a high internal consistency. In other words, all variables in this study are reliable. The validity was identified based on $\mathrm{r}$ correlation, wherein if r-experimental gives a greater value compared to $\mathrm{r}$ critical (df $=\mathrm{n}-2$ and sig 0.05$)$ then the items are valid. According to that, all question items in this research were evidently valid.

\section{Hypothesis Test}

To formally test hypotheses, SPSS was performed to test Hypothesis 1 and Hypothesis 2, using SPSS PROCESS developed by Hayes [20] to test Hypothesis 3 and Hypothesis 4. The analysis results are presented in the table 3 and table 4 as follows.

TABLE III. REGRESSION ANALYSIS

\begin{tabular}{|l|l|l|l|}
\hline & Model 1 & Model 2 & Model 3 \\
\hline Perceived Benefit & $0.586^{\mathrm{a}}$ & $.5807^{\mathrm{a}}$ & \\
\hline Perceived Risk & -0.058 & & -0.0556 \\
\hline Gender & & -0.0818 & -0.0869 \\
\hline Perceived Benefit*Gender & -0.0716 & $0.2210^{\mathrm{b}}$ \\
\hline Perceived Risk*Gender & \multicolumn{3}{|c|}{ a. significant at the 0.01 level (2-tailed) } \\
b. significant at the 0.05 level (2-tailed)
\end{tabular}

As is shown in the table 3, perceived benefit delivered a significant effect on FinTech continuance intention $(\beta=0.568$, $\mathrm{p}<0.01)$, thus, H1 was supported. On the other hand, the perceived risk had no significant effect on FinTech continuance intention $(\beta=-0.058, p>0.05)$, dismissing H2. It was also 
found that perceived benefit provides a greater influence than perceived risk, indicating the respondents' volition to adopt FinTech in Indonesia.

Based on the respondents' characterization, it has been identified that the respondents were consisted of $59.27 \%$ women and $40.37 \%$ men. Table III points that gender did not moderate the effect of perceived benefit on FinTech continuance intention $(\beta=-0.0716, p>0.05)$. Hence, H3 could not be supported. Furthermore, the result explained the effect of perceived risk on FinTech continuance intention was proved to be moderated by gender $(\beta=0.2210, \mathrm{p}<0.05)$, providing support for $\mathrm{H} 4$.

TABLE IV. CONDITIONAL EFFECTS OF THE FocAl PREDICTOR AT VALUES OF THE MODERATOR

\begin{tabular}{|c|l|l|l|l|}
\hline GD & \multicolumn{1}{|c|}{ Effect } & Se & t & p \\
\hline-0.5927 & -0.1866 & 0.0740 & -2.5234 & 0.0123 \\
\hline 0.4073 & 0.0343 & 0.0750 & 0.4579 & 0.6474 \\
\hline
\end{tabular}

Table 4 presents the findings on two different regressions: the regression for perceived risk as a predictor of FinTech continuance intention (1) when the value for gender is - .5927 (i.e., low), as male were coded as zero, this represents the value for men; and (2) when the value for gender is .4073 (i.e., high), as female were coded as 1 , this represents the women. The significant influences of the perceived benefit and risk on FinTech continuance intention were only visible in the men group. Although the perceived benefit gave significant effect $(\beta=-0.1866, p<0.05)$ on the continuance intention for men, it goes differently for women. These results tell us that the relationship between perceived risk and FinTech continuance intention between men and women are different, as for men, perceived risk increases as the level of FinTech continuance intention decreases, whereas for women, they tend to adopt FinTech without any risk consideration.

\section{DISCUSSION}

FinTech advent in Indonesia started in 2015 indicated by an establishment of Indonesian FinTech Association (Asosiasi FinTech Indonesia (AFI)). However, Indonesia is still left behind in FinTech development compared to Asian countries such as China, Hong Kong, and India. Many people are still more accustomed with conventional financial services rather than the existing FinTech. Ryu conveyed that the presence of traditional financial sector that has been applied for a long period happens to become a hindrance for FinTech development. This casts a doubt upon the potential and success of FinTech business among financial institutions and IT companies.

This study attempts to bring some insight into whether the continuous use of FinTech is influenced by positive factors (perceived benefits) or negative factors (perceived risk) to the users. In getting a better approach, FinTech users were categorized into men and women to investigate different behaviors attributed to gender level, especially in Generation $\mathrm{Z}$ that holds strong possibility to be the future FinTech users. In accordance to the findings, perceived benefit significantly affects FinTech continuance intention. The greater perceived benefit will promote more effect to FinTech continuance intention. This shows that Generation $\mathrm{Z}$ expects a high value of FinTech usage. Therefore, FinTech companies better off moving forward to evolve their business and meet the demands. After all, these results make a good agreement with some previous studies $[7,14,21,22]$. The result of perceived risk went oppositely which shows no significant effect on FinTech continuance intention. In short, the Generation $\mathrm{Z}$ assumes that using FinTech is not related to any concerning risk, instead, they benefit more from FinTech than conventional financial services. The FinTech users from Generation $\mathrm{Z}$ are capable in risk management and to address the problem such as violation of personal privacy or transaction data. This is supported by the fact that Generation $\mathrm{Z}$ is quite accustomed to technology and prefers practicality.

On the other hand, there was no gender effect on the links between perceived benefit and FinTech continuance intention, meaning that there is no difference in benefit attained by both men and women of Generation Z. This is possibly because both genders have been familiar with different kind of FinTech. Moreover, the possibility of variations in gender impact on FinTech continuance intention can be measured not only by dichotomous measure of gender but more inherently based on the degree or level of femininity or masculinity [23].

Hereinafter in table 3, gender acts as the moderation variable that influences the perceived risk and FinTech continuance intention. As is observed, men and women gained different effects from the interaction between perceived risk and FinTech continuance intention. Apart from that, table 4 shows a significant effect of the perceived risk on the FinTech continuance intention only in the group of men. Specifically, for men, as perceived risk increases the level of FinTech continuance intention decreases. As for women, they will adopt FinTech without considering the risks. Based on a survey by OJK, men are more capable of using technology and various kinds of financial services. As the evidence, the National Survey of Financial Literacy (Survei Nasional Literasi Keuangan) carried out by OJK in 2019 revealed that the literacy and financial inclusion indexes of men were $39.94 \%$ and $77.24 \%$, comparatively higher than women with values of $36.13 \%$ and $75.15 \%$, respectively. This is why men are more careful in using financial services, including FinTech. The results of this study are in line with previous research which examined the gender difference issue in the adoption of mobile payment [23,24], social media [25], and online purchase [26].

\section{CONCLUSION}

The significant determinants promoting FinTech continuance intention among Generation $\mathrm{Z}$ in Indonesia and the effects generated by gender difference have been examined in this study. According to the empirical results, perceived benefit promotes customers' continuance intention significantly, while the perceived risk showed the opposite way. Nevertheless, the 
effect of perceived benefit on FinTech continuance intention was evidently not moderated by gender. Otherwise, gender moderation was found in perceived risk and consumer continuance intention to use FinTech. The relationship between perceived risk and FinTech continuance intention was described giving different results for men and women. Particularly, for men, the perceived risk happens to increase along with the decrease of FinTech continuance intention.

Despite the fact that our research offers certain contributions, some limitations and further research directions need to be discussed. First, as the respondents only included Indonesian users, future studies can be undertaken overseas to examine the generalizability of our proposed theoretical model further. Second, future research can integrate customers' age, experience and nationality as moderators in the theoretical model in order to examine the existence of any behavioral difference in various user samples categorized by these characteristics. Third, future studies can be done to identify the presence of possible significant difference in perceived benefit, perceived risk, and FinTech continuance intention within various types of FinTech. Fourth, further studies can specify the benefit and risk dimension that might affect FinTech continuance intention.

\section{REFERENCES}

[1] L. Zavolokina, M. Dolata, and G. Schwabe, "FinTech-What's in a name?," Proceedings in International Conference on Information Systems, Dublin, pp. 1-19, 2016

[2] P. Padmanaban and H. K. Y. Soo, "Catching the Fintech Wave A survey on FinTech in Malaysia," [Online]. Retrieved from https://www.pwc.com/my/en/assets/publications/2016pwc-aicbcatching-thefintech-wave.pdf

[3] R. Chan, "Asian Regulator Seek FinTech Balance," Finance Asia, 2015, [Online]. Retrieved http://www.financeasia.com/News/401588,asian-regulators-seekfintech-balance.aspx.

[4] H.S. Ryu, "What makes users willing or hesitant to use Fintech?: the moderating effect of user type," Ind. Manag. Data Syst., vol. 118, no. 3, pp. 541-569, 2018.

[5] J. Jurison, "The role of risk and return in information technology outsourcing decisions", Journal of Information Technology, vol. 10, no. 4, p. 239, 1995.

[6] H.S. Chiang, "Continuous usage of social networking sites: the effect of innovation and gratification attributes", Online Information Review, vol. 37, no. 6, pp. 851-871, 2013.

[7] C. Kim , M. Mirusmonov, and I. Lee, "An empirical examination of factors influencing the intention to use mobile payment," Computers in Human Behavior, vol. 26, no. 3, pp. 310-322, 2010.

[8] T.P. Liang, and Y.H. Yeh, "Effect of use contexts on the continuous use of mobile services: the case of mobile games", Personal and Ubiquitous Computing, vol. 15, no. 2, pp. 187-196, 2011.
[9] T. Zhou, "An empirical examination of continuance intention of mobile payment services", Decisioån Support Systems, vol. 54, no. 2, pp. 1085 1091, 2013

[10] K. Rouibah, P.B. Lowry, and Y. Hwang, "The effects of perceived enjoyment and perceived risks on trust formation and intentions to use online payment systems: new perspectives from an Arab country", Electronic Commerce Research and Applications, vol. 19, pp. 33-34, 2016

[11] Q. Sun, C. Wang, and H. Cao, "An Extended TAM for Analyzing Adoption behavior of mobile commerce", The eight international conference on mobile business, IEEE, Dalian, 2009.

[12] F.J. Lie'bana-Cabanillas, J. Sa'nchez-Ferna'ndez and F. Mun oz-Leiva, "Role of gender on acceptance of mobile payment", Industrial Management \& Data Systems, vol. 114, no. 2, 2013.

[13] U. Sekaran, Metode Penelitiaan Bisnis. Jakarta: Salemba Empat, 2006.

[14] H.S. Ryu, "What makes users willing or hesitant to use Fintech?: The moderating effect of user type", Industrial Management \& Data Systems, 2018

[15] J. Park, E. Amendah, Y. Lee, H. Hyun, "M-payment service: Interplay of perceived risk, benefit, and trust in service adoption", Hum. Factors Man., pp. 1-13, 2018.

[16] T. Tanadi , B. Samadi, and B. Gharleghi, "The Impact of Perceived Risks and Perceived Benefits to Improve an Online Intention among Generation-Y in Malaysia", Asian Social Science, vol. 11, no. 26, 2015.

[17] L.M. Hunter, C.J. Kasouf, K.G. Celuch, and K.A. Curry, "A classification of business-to-business buying decisions: risk importance and probability as a framework for e-business benefits," Industrial Marketing Management, vol. 33, pp. 145-54, 2004.

[18] C. Gan and W. Wang, "The influence of perceived value on purchase intention in social commerce context," Internet Research, vol. 27, issue 4, pp. 772-785, 2017.

[19] J. Pallant, "SPSS survival manual : A step by step guide to data analysis using IBM SPSS (4th ed.)", Crows Nest, NSW: Allen \& Unwin, 2013.

[20] A.F. Hayes, "Introduction to Mediation, Moderation, and Conditional Process Analysis, Second Edition: A Regression-Based Approach", Guilford Publications, 2017.

[21] Okazaki and F. Mendez, "Exploring convenience in mobile commerce: Moderating effects of gender", Computers in Human Behavior, vol. 29, pp. 1234-1242, 2013.

[22] Y.C. Shen, C.Y. Huang, C.H. Chu, and C.T. Hsu, "A benefit-cost perspective of the consumer adoption of the mobile banking system," Behaviour \& Information Technology, vol. 29, no. 5, pp. 497-511, 2010.

[23] S.L. Bem, "Gender scheme theory: A cognitive account of sex typing", Psychological Review, vol. 88, no. 1981, pp. 354-364, 2010.

[24] Z. Shao, L. Zhang, X. Li, and Y. Guo, "Antecedents of Trust and Continuance Intention in Mobile Payment Platforms: The Moderating Effect of Gender", Electronic Commerce Research and Applications, 2018 .

[25] K.S. Kim, S.C.J. Sin, and T.I. Tsai, "Individual Differences in Social Media Use for Information Seeking", The Journal of Academic Librarianship, 2014.

[26] Y.B. Chiu, C.P. Lin, and L.L. Tang, "Gender differs: assessing a mode of online purchase intentions in e-tail service", International Journal of Service Industry Management, 2005. 